\title{
KESESUAIAN DAN DAYA DUKUNG WISATA BAHARI DI PERAIRAN BANDENGAN KABUPATEN JEPARA JAWA TENGAH
}

(Suitability and carrying capacity of marine tourism in Bandengan water, Jepara, Central Java)

\author{
Juliana $^{1}$, Lachmuddin Sya' ${ }^{1}{ }^{2}{ }^{2}$ dan Muhammad Zainuri ${ }^{2}$ \\ ${ }^{1}$ Politeknik Perikanan Negeri Tual. \\ ${ }^{2}$ Universitas Diponegoro Semarang.
}

\begin{abstract}
Bandengan waters are marine tourism area which should be preserved, so that it is necessaty to analyze the suitability and carrying capacity of the area. This study aims to determine the suitability of marinetourism using tourism suitability indices method based on biophysical parameters. Biophysical-yater parameters used as suitability criteria are coral reef coverage, harmful biota, depth, brightness, curren velocity, bottom substrate, slope and width of the beach, land cover and type of beach and the availablity of fresh water. Analysis of the carrying capacity of the area was conducted to determine the width of the area and the carrying capacity for each category of marine tourism. Based on the analysis of the suitabllity of marine tourism and the carrying capacity of the region, there are two categories of tourism which are very suitable to be developed in Bandengan waters. The first category is recreation and swimming tith total area of 52.46 hectares and a capacity of 27,978 visitors. The second category is boating, banama boat and jet ski with a total area of 99.68 hectares and a capacity of 11,961 visitors.

Kata kunci: marine tourism, suitability analysis, carrying capacity.

Perairan Bandengan merupakan kawasan wisata bahari yang harus dijaga kelestariannya, sehingga perlu dilakukan analisa kesesuaian dan daya dukung kawašan. Penelitian ini bertujuan untuk mengetahui kesesuaian wisata bahari dengan metode indeks kesesuaian wis ta berdasarkan parameter biofisik perairan. Parameter biofisik perairan yang dijadikan kriteria yaitu tutupan terumbu karang, biota berbahaya, kedalaman, kecerahan, kecepatan arus, material dasar perairan, keminingan dan lebar pantai, penutupan lahan dan tipe pantai serta ketersediaan air bersih. Analisa daya dukungkawasan dilakukan untuk mengetahui luas kawasan dan daya tampung untuk masing-masing kategori misata bahari. Berdasarkan hasil analisa terhadap kesesuaian wisata bahari dan daya dukung kawasan, adaduakategori wisata yang sangat sesuai untuk dikembangkan pada perairan Bandengan. Kategori wisata bahari yang pertama yaitu rekreasi dan renang dengan luas kawasan 52,46 ha dan daya tampung 27,978 wisatałyan॰Kategori kedua yaitu berperahu, banana boat dan jet ski dengan luas kawasan 99,68 ha dan daya tampung 11.961 wisatawan.
\end{abstract}

Keywords: wisata bahari, añalistis kesesuaian, daya dukung.

\section{PENDAHULUAN}

Wisata Bahari merupakan salah satu jenis wisata yang berkembâng di Indonesia. Hal ini disebabkan Indonesia merupakan negara kepulauan dan memiliki potensi sumberdaya pesisir dan lautan yang sangat besar (Haris dan Godwin, 2002). Sumberdaya pesisir dan lautan yang dapat ditemui di Indonesia antara lain populasi ikan hias yang diperliicakan mencapai sekitar 263 jenis, terumbu karang, padang lamun, hutan mangrove dan berbagai bentang alam pesisir yang unik. Kondisi pemandangan alamiah tersebutlah yang menjadi daya tarik yang sangat besar bagi wisatawan. Daerah yang memiliki potensi pesisir dan pantai, pengembangan pariwisata pantai atau bahari merupakan suatu tantangan yang menjanjikan, mengingat pariwisata merupakan sektor yang mampu membe- rikan kontribusi tinggi bagi perekonomian daerah (Hunger dan Wheelen, 2003).

Perairan Bandengan merupakan salah satu wilayah yang berada di Kabupaten Jepara dengan luas wilayah 586 ha dengan panjang garis pantai $3,85 \mathrm{~km}$ dan memiliki air yang bersih, hamparan pasir putih yang luas dan memiliki terumbu karang. Keindahan alam perairan Bandengan ini menjadi daya tarik bagi wisatawan, sehingga perairan Bandengan telah dijadikan sebagai salah satu tujuan wisata bahari. Berdasarkan data dari Dinas Pariwisata Kabupaten Jepara, tahun 2011 jumlah wisatawan yang datang ke Pantai Bandengan terus mengalami peningkatan. Pada tahun 2006 jumlah wisatawan adalah 61.657 dan pada tahun 2011 meningkat hingga mencapai 203.637 atau mengalami peningkatan sebesar 3,5 kali dalam waktu 5 tahun. Peningkatan jumlah wisatawan dan aktivitas wisata bahari yang dilakukan jika tidak dike- 
lola secara tepat akan berpengaruh terhadap lingkungan. Hal ini disebabkan perairan Bandengan termasuk wilayah pesisir yang rentan terhadap berbagai perubahan ekosistem. Berdasarkan hasil penelitian Supriharyono (2007), menyatakan bahwa Pantai Bandengan telah mengalami penurunan kualitas lingkungan terutama dalam hal tutupan terumbu karang hidup hanya sebesar 5\% dan hanya berupa koloni-koloni karang baru atau berupa koloni-koloni karang yang tidak seluruh koloninya dalam kondisi hidup. Hal ini di dukung juga dengan data dari Dinas Kelautan dan Perikanan Kabupaten Jepara (2010) yang menyatakan bahwa ekosistem terumbu karang yang ada di perairan Bandengan telah mengalami kerusakan dan hanya terdapat 17,5 ha terumbu karang yang juga dalam kondisi rusak berat. Kerusakan terhadap terumbu karang yang terjadi di perairan Bandengan merupakan akibat dari aktivitas yang terdapat dalam kawasan perairan Bandengan, baik aktivitas wisata, penangkapan ikan dan pengambilan terumbu karang untuk dijual dan dijadikan hiasan.

Aktivitas wisata bahari merupakan salah satu faktor penyebab terjadinya perubahan ekosistem di perairan Bandengan. Hal tersebut merupakan akibat dari aktivitas wisata bahari yang dilakukan belum disesuaikan dengan kondisi biofisik dan daya dukung kawasan. Pengembangan wisata bahari di perairan Bandengan harus sesuai dengan kondisi biofisik perairan dan daya dukung $\mathrm{kat}$ san. Penelitian ini bertujuan untuk mengahalisa kesesuaian wisata bahari (kategori rekreasi dan berenang, kategori selam permukaan/snorkeling, kategori selam/scuba diving dan kategori berperahu, banana boat dan jet ski) berdasarkan parameter biofisik perairan dan daya dukung kawasan wisata bahari di perairan Bandengan. Hal ini bermanfaat untuk mencegah terjadinya kerusakan lingkungan yang terus-meneru pada kawasan wisata bahari Bandengan, sertamenjadi dasar dalam pengelolaan kawasan wisata bahari di perairan Bandengan.

Stasiun pengamatan pada penelitian ini terdirRdri-sembilan titik dan ditentukan berdasarkan letak lokasi yang dapat mewakili keadaan lokasi penelitian secara umum dan merupakan kawasan yang dapat dimanfaatkan untuk kegiatan wisata bahari di perairan Bandengan (Gambar 1). Pengambilan data parameter biofisik perairan dilakukan selama tiga bulan yaitu Agustus-Oktober 2011.

Analisis kesesuaian wisata bahari diklasifikasikan dalam tiga kelas kesesuaian yaitu Sangat Sesuai (S1), Sesuai (S2), dan Tidak Sesuai (N). Pe- netapan kelas kesesuaian didasarkan pada nilai yang diperoleh dari penjumlahan hasil perkalian antara kategori nilai setiap parameter dan bobot untuk setiap kegiatan wisata bahari. Parameter yang digunakan dalam menentukan kesesuaian wisata bahari kategori rekreasi dan berenang, yaitu kedalaman, tipe pantai, lebar pantai, biota berbahaya, material dasar perairan, kecepatan arus, kemiringan pantai, kecerahan, penutupan lahan pantai dan ketersediaan air tawar. Parameter untuk kategori snorkeling yang diukur sama denganpada kategori selam, yaitu kecerahan, tutupqn karting, material dasar perairan, biota berbahay de tatan arus, dan kedalaman terumbu karsns. Sedangkan parameter untuk kategori berperatu, Jet ski dan $b a$ nana boat adalah kedalaman dan lecepatan arus. Analisa daya dukung kawasan (DDK) yang dilakukan dalam penelitian ini yaitu menghitung luas kawasan yang sesuai pada setiap aktivitas wisata dan menentukan jumlah maksimum pengunjung yang secara fisik dapat ditampung pada suatu kawasan yang tedah disediakan pada waktu tertentu tanpa menumbukan gangguan bagi lingkungan dan manusia yang ada di sekitarnya.

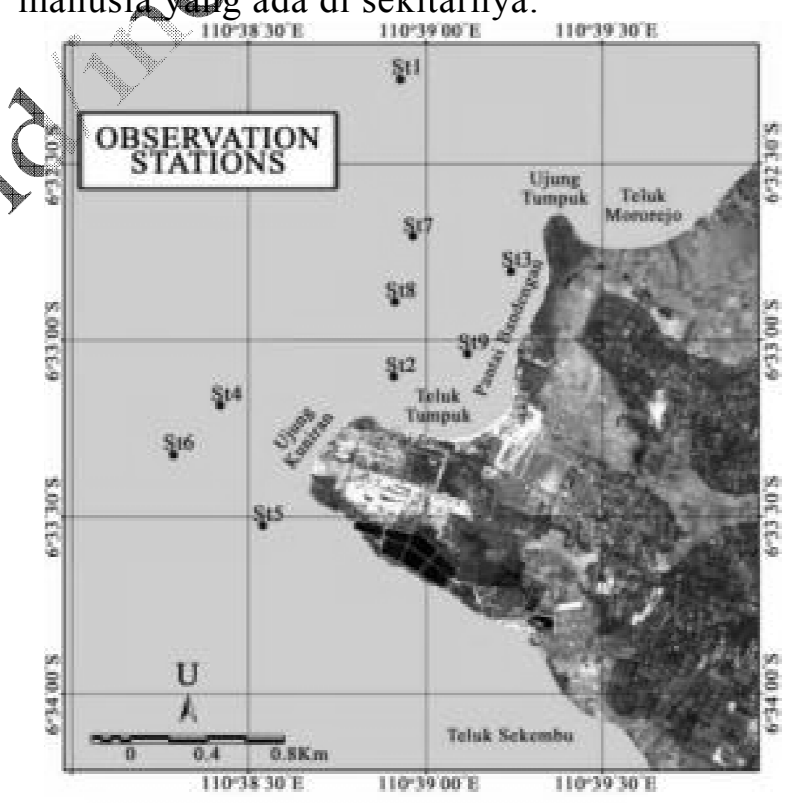

Gambar 1.Peta stasiun penelitian di perairan Bandengan.

Figure 1. Observation stations at Bandengan waters. (Citra Satelit Quick bird, 2007; Peta Lingkungan Pantai Indonesia, 2000; Peta Rupabumi Indonesia, 1999).

Daya dukung kawasan dihitung dengan rumus (Yulianda, 2007): $\mathrm{D}_{\mathrm{DK}}=\mathrm{K} \frac{\mathrm{Lp}}{\mathrm{Lt}} \times \frac{\mathrm{Wt}}{\mathrm{Wp}}$

Ket.: $\mathrm{D}_{\mathrm{DK}}$ (daya dukung kawasan); $\mathrm{K}$ (potensi ekologis pengunjung per satuan unit area); Lp (luas area atau panjang area yang dapat dimanfaatkan); Lt (unit area untuk kategori tertentu); Wt (waktu yang disediakan oleh kawasan untuk kegiatan wisata dalam 1 hari); Wp (waktu yang dihabiskan oleh pengunjung untuk setiap kegiatan tertentu). 
Tabel 1. Prediksi potensi ekologis, luas area, waktu pengunjung dan waktu kawasan.

Table 1. Predicted ecological potency, unit area, visitor time and available time.

\begin{tabular}{lcccc}
\hline $\begin{array}{c}\text { Jenis } \\
\text { kegiatan }\end{array}$ & $\begin{array}{c}\sum \\
\text { pengunjung } \\
\mathbf{K}\end{array}$ & $\begin{array}{c}\text { Unit } \\
\text { Area } \\
\mathbf{L t}\left(\mathbf{m}^{\mathbf{2}}\right)\end{array}$ & $\begin{array}{c}\mathbf{W p} \\
\mathbf{( j a m )}\end{array}$ & $\begin{array}{c}\mathbf{W t} \\
\mathbf{( j a m})\end{array}$ \\
\hline Rekreasi & 1 & 50 & 3 & 8 \\
dan berenang & & & & \\
Snorkeling & 1 & 250 & 2 & 6 \\
Selam & 1 & 500 & 3 & 6 \\
$\begin{array}{l}\text { Berperahu, } \\
\text { jets ski dll. }\end{array}$ & 1 & 500 & 1 & 8 \\
Sumber: Yulianda (2007) & & & \\
\hline
\end{tabular}

Yulianda (2007) menyatakan, waktu kegiatan pengunjung (Wp) dihitung berdasarkan lamanya waktu yang dihabiskan pengunjung untuk melakukan kegiatan wisata. Waktu pengunjung juga diperhitungkan berdasarkan waktu yang disediakan oleh suatu kawasan wisata. Waktu kawasan adalah lama waktu area dibuka dalam satu hari. Waktu kawasan pada wisata bahari Bandengan didasarkan pada jam kerja yaitu dari pukul 08.00 16.00 WIB (8 jam/hari). Potensi ekologis, unit area, waktu pengunjung dan waktu kawasan dapat dilihat pada Tabel 1 dan diperoleh hasil wawancara pada penelitian awal secara langsung pada wisatawan.

\section{HASIL DAN PEMBAHASAN}

\section{Kondisi biofisik perairan Bandengan Terumbu karang}

Hasil pengamatan yang dilakukan tefhadap persentase tutupan terumbu karang padá perairan Bandengan, menunjukkan bahwa terumbu karang berada pada kategori yang buruk, karena persentase tutupannya hanya berkisar $0-24,52 \%$. Kerusakan ini disebabkan oleh berbagai faktor baik yang berasal dari kegiatan manusia maupun kerusakan yang terjadi akibat ałam. Salah satu faktor yang menyebabkan kerusakay terumbu karang ini adalah masih adanyarmasyarakat yang mengambil karang untuk dijufal.

Menturut Supriharyono (2007), kerusakan terumbu karang dapat disebabkan oleh faktor fisik, kimia dan biologi. Terumbu karang sangat sensitif terhadap pengaruh lingkungan, baik yang bersifat fisik seperti kerusakan akibat aktivitas manusia, pencemaran bahan kimia maupun kerusakan akibat aktivitas biologis (Burke et al., 2002; Dahuri, 2003). Kondisi terumbu karang yang berada di perairan yang termasuk dalam kategori yang buruk menyebabkan kegiatan wisata bahari kategori snorkeling dan selam tidak dapat dilakukan, karena tujuan utama dari wisata ini adalah menikmati pemandangan bawah laut yang di dominasi oleh keberadaan terumbu karang pada suatu perairan.

\section{Biota berbahaya}

Hasil pengamatan yang dilakukan terhadap biota berbahaya dengan indikator utama adalah bulu babi pada penelitian ini menyatakan tidak ditemukan adanya biota tersebut. Bulu babi dijadikan indikator utama karena memiliki duri yang beracun dan jika terinjak oleh wisatawan yang sedang melakukan aktivitas seperti renang, snorkeling dan selam, duri tersebut akan patah karena memiliki sifat yang rapuh, sehingga akan tertanam dalam kulit yang dapat mengakibatkan infeksi. Meskipun bulu babi termasuk biota berbahaya bagi kegiatan wisata bahari tetapi memiliki peranan eukup besar pada ekosistem terumbu karang, yattu talam jaringan makanan memiliki berbagai kedudukan, yang meliputi sebagai herbivora, karnivora, omnivora ataupun sebagai pemakan detritus (Birkeland, 1989 dan Hernandez, 2006)

\section{Kedalaman perairain}

Kedalamán perairran Bandengan pada hasil yaitu $1,5-15$ m. Kedalaman perairan ini merupakan salah satu parameter fisik yang perlu untuk diketahui. Kedalaman pada penelitian ini merupakan fakto utama yang digunakan untuk menentukan lokasi wisata bahari, karena menurut hasil peneljtian Edward et al. (2002), menyatakan bahwa kedalaman perairan yang berkisar 3,2-35,5 m masih layak dijadikan lokasi wisata bahari berenang, snorkeling dan selam.

\section{Kecerahan}

Hasil pengukuran kecerahan pada perairan Bandengan hanya berkisar 1-2 m. Kecerahan juga merupakan ukuran transparansi perairan, yang dapat ditentukan secara visual. Nilai kecerahan pada umumnya dinyatakan dalam satuan meter. Nilai kecerahan sangat dipengaruhi oleh keadaan cuaca, waktu pengukuran, kekeruhan dan padatan tersuspensi. Kecerahan di perairan Bandengan sangat rendah karena nilai TSS (Total Suspended Solid) sangat tinggi, yang menyebabkan kekeruhan tinggi dan berakibat daya tembus cahaya matahari ke dalam perairan sangat rendah.

\section{Kecepatan arus}

Kecepatan arus sangat berpengaruh terhadap aktivitas yang akan dilakukan pada suatu wilayah perairan. Hasil pengukuran terhadap kecepatan arus di perairan Bandengan adalah 0,07-0,42 m/ detik. Kecepatan arus sangat dipengaruhi oleh perbedaan musim, pada musim Barat kecepatan arus relatif lebih tinggi dibandingkan dengan pada musim Timur (Riyadi et al., 2005). 
Kecepatan arus yang layak untuk wisata bahari berenang berkisar $0,20-0,40 \mathrm{~m} /$ detik, snorkeling $0,15-0,4 \mathrm{~m} /$ detik, selam $0,15-0,40 \mathrm{~m} /$ detik dan olah raga air seperti jet ski, banana boat, berperahu berkisar 0,15-0,40 m/detik. Berdasarkan hasil penelitian, maka kecepatan arus di perairan Bandengan pada beberapa stasiun masih layak untuk wisata bahari renang dan olah raga air, sedangkan untuk wisata snorkeling dan selam meskipun dari parameter kecepatan arus layak tetapi parameter utama seperti terumbu karang dan kecerahan tidak mendukung kegiatan snorkeling dan selam.

\section{Material Dasar Perairan}

Berdasarkan hasil analisa jenis material dasar di perairan Bandengan, diperoleh bahwa material dasar perairan terdiri dari kerikil, pasir, lumpur dan lempung. Kerikil sebesar 2,54-35,11\%, pasir 0,30-94,19\%, lumpur 1,32-89,71\% dan lempung sebesar 10,67-22,22\%. Material dasar perairan merupakan salah satu faktor yang mempengaruhi ekosistem perairan dan sangat berpengaruh terhadap kekeruhan perairan serta salah satu faktor penunjang untuk kelayakan aktivitas wisata bahari.

\section{Kemiringan, lebar, tipe dan penutupan pantai}

Berdasarkan hasil pengukuran diperoleh kemiringan pantai sebesar 5-15 dan lebar pantai 12,3-67,5 m. Hasil tersebut menunjukkan bahwa perairan Bandengan termasuk landai dan memilik lebar pantai yang dapat mendukung kegiatan wisata bahari yang akan dikembangkan di perairan tersebut. Keadaan pantai yang demikian menyebabkan pantai Bandengan banyak dikunjungi wisatawan untuk melakukan aktivitas (i) sekitar pantai sambil menikmati pemandangan pantai dan menikmati matahari terbenam. Hall ini di dukung pula dengan lahan terbuka yang dimiliki oleh perairan Bandengan serta hanparan pasir putih.

\section{Ketersediaanair tawar}

Ketêrsediaan air tawar yang cukup di perairan Bandengan dapat memenuhi kebutuhan wisatawan. Fasilitas berupa toilet dan kamar mandi tela tersedia air bersih, sehingga dapat digunakan pengunjung untuk membersihkan diri setelah melakukan aktivitas renang di perairan Bandengan. Fasilitas tersebut dikelola oleh Dinas Pariwisata Kabupaten Jepara.

\section{Analisa kesesuaian wisata bahari Kategori rekreasi dan berenang}

Hasil analisa kesesuaian wisata berdasarkan parameter biofisik di perairan Bandengan, pa- da musim Timur dihasilkan tiga kategori kelas kesesuaian untuk wisata bahari kategori rekreasi dan berenang, yaitu sangat sesuai, sesuai dan tidak sesuai. Berdasarkan hasil pengukuran seluruh parameter perairan yang dijadikan dasar dalam perhitungan indeks kesesuaian wisata pada setiap stasiun penelitian, analisa data dilakukan dengan menggunakan bantuan perangkat lunak ArcGIS untuk memperoleh peta kesesuaian wisata bahari kategori rekreasi dan berenang (Gambar 2)

Parameter yang memiliki bobot yang tertinggi untuk menentukan indeks kesesuáian wüsata kategori rekreasi dan berenang adałâh kedalaman, tipe dan lebar pantai. Hal ini disebabkan karena ketiga parameter tersebut dianggap paling penting bagi aktivitas rekreasi dan berenang. Hal tersebut didukung dengan hasil penelitian Bahar dan Rahmadi (2011), yang menyatakan bahwa pemilihan lokasi yang direneanakan untuk tujuan wisata bahari tidak terlepas dari keadaan lokasi.

\section{Kategori selampermukaan}

Analisa data berdasarkan parameter biofisik di perairan Bandengan, menghasilkan dua kategori kelas Kesesuaian untuk wisata bahari kategori selam permukaan, yaitu Sesuai dan Tidak Sesuai. Berdasarkan hasil pengukuran seluruh parameter perairan yang dijadikan dasar dalam perhitungan indeks kesesuaian wisata pada setiap stasiun penelitian, kemudian dianalisa data dengan menggunakan bantuan perangkat lunak ArcGIS untuk memperoleh peta kesesuaian wisata bahari kategori selam permukaan (Gambar 2).

Kawasan dengan kategori sesuai mempunyai faktor pembatas, yaitu keberadaan terumbu karang yang buruk, sehingga menyebabkan penelitian ini tidak merekomendasikan adanya kegiatan selam permukaan di perairan Bandengan. Ini disebabkan karena tujuan utama dari wisata selam permukaan adalah melihat keindahan bawah laut berupa hamparan terumbu karang dan organisme yang hidup pada terumbu karang. Pada kawasan dengan kategori Sesuai dengan beberapa faktor pembatas perlu dilakukan rehabilitasi terhadap ekosistem terumbu karang, sehingga pada waktu yang akan datang dapat kembali dijadikan sebagai daerah tujuan wisata bahari kategori selam permukaan. Pragawati (2009), menyatakan juga bahwa lokasi perairan yang sesuai bersyarat harus dilakukan rehabilitasi kawasan terutama terhadap ekosistem terumbu karang yang merupakan tujuan utama wisata selam permukaan. 

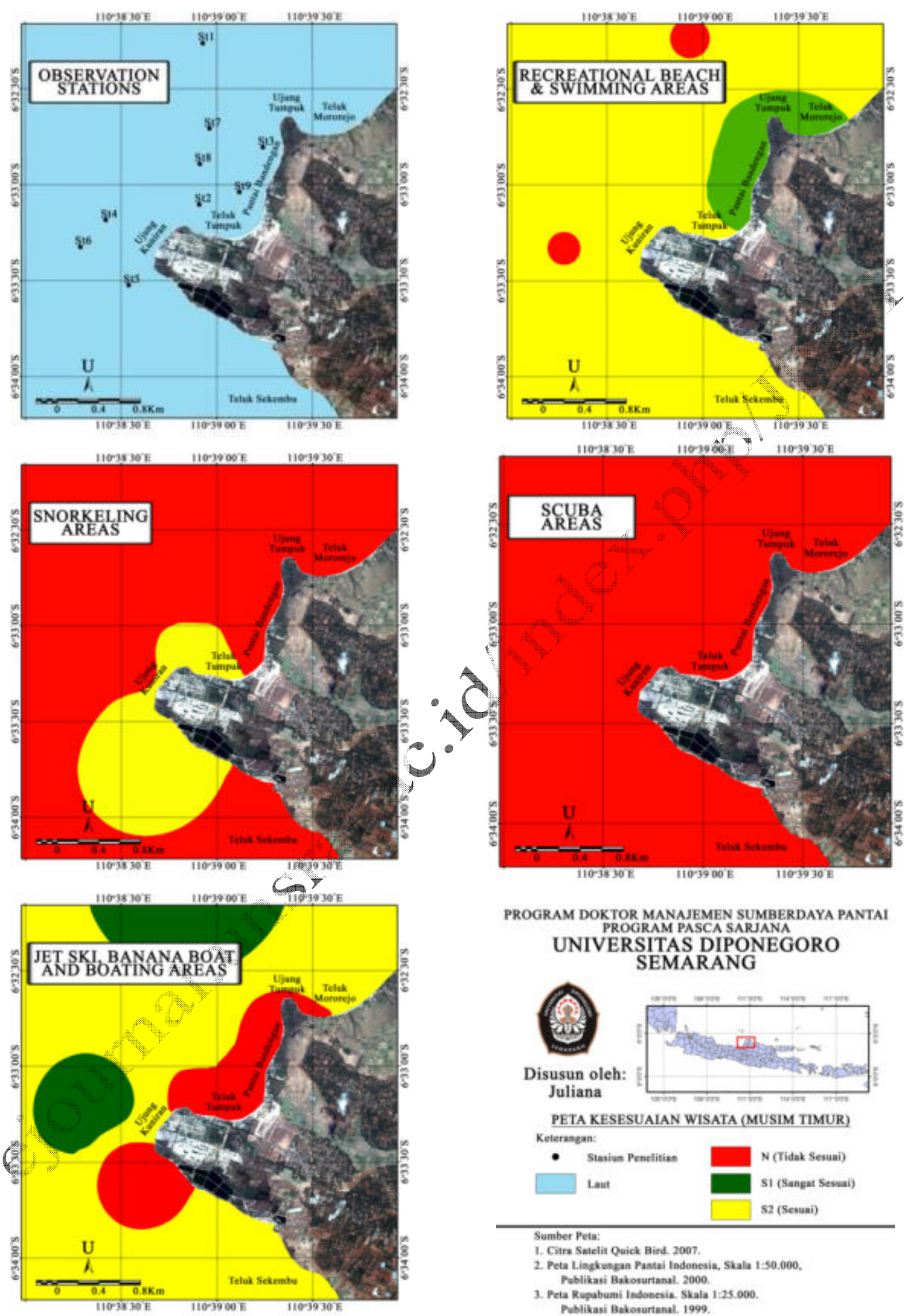

Gambar 2.Peta lokasi kesesuaian wisata bahari berdasarkan kategori di perairan Bandengan, Jawa Tengah. Figure 2. Map location the suitability of nautical tourism based on category in Bandengan waters, Central Java. 


\section{Kategori selam}

Berdasarkan hasil perhitungan indeks kesesuaian wisata, menunjukkan bahwa perairan Bandengan tidak sesuai untuk kegiatan wisata bahari kategori selam, karena lokasi tersebut memiliki faktor pembatas. Faktor pembatas utama di perairan Bandengan adalah kecerahan dan ekosistem terumbu karang yang sangat buruk. Hasil pengukuran seluruh parameter perairan yang dijadikan dasar dalam perhitungan indeks kesesuaian wisata pada setiap stasiun penelitian, kemudian dianalisa dengan menggunakan perangkat lunak ArcGIS untuk memperoleh peta kesesuaian wisata bahari kategori selam (Gambar 2).

Senoaji (2009) menyatakan bahwa lokasi yang dapat dijadikan sebagai kawasan wisata bahari kategori selam harus memenuhi 6 parameter kualitas perairan. Parameter tersebut adalah kecerahan, jenis karang, tutupan karang hidup, jenis ikan karang, kecepatan arus dan kedalaman dasar perairan. Kondisi perairan Bandengan tidak memenuhi persyaratan tersebut, sehingga tidak dapat dijadikan kawasan wisata bahari kategori selam.

\section{Kategori berperahu, banana boat dan jet ski}

Hasil perhitungan indeks kesesuaian wisata menghasilkan tiga kategori berdasarkan kelas kesesuaian yaitu Sangat Sesuai, Sesuai dan Tidak Sesuai. Berdasarkan hasil yang diperoleh pada setiap stasiun dengan mempertimbangkan seluruh parameter untuk wisata berperahu, banana boat dan jet ski, kemudian dianalisa dengă Arc GIS sehingga diperoleh peta kesesuaian wisata bahari kategori tersebut (Gambar 2).

\section{Analisa Daya Dukung kawasan Wisata Bahari}

Berdasarkan hasilanalisa daya dukung kawasan untuk kegiatân wisata bahari kategori rekreasi dan berenang_diperoleh luas kawasan sebesar 52,46 ha dengan daya tampung wisatawan sebanyak 27.978 orang. Sedangkan hasil analisa daya dukung kawasan untuk kegiatan wisata bahari kategoriselam permukaan dan selam di kawasan wisata bahari Bandengan termasuk dalam kategori Tidak Sesuai, sehingga daya dukung kawasan tidak terpenuhi. Hasil analisa daya dukung kawasan untuk kegiatan wisata bahari kategori berperahu, banana boat dan jet ski diperoleh luas kawasan yang sangat sesuai sebesar 99,68 ha dengan daya tampung wisatawan sebanyak 11.961 orang.

Daya dukung kawasan untuk wisata bahari tidak terlepas dari kondisi biofisik perairan. Dodds (2007) menyatakan bahwa kegiatan wisata bahari sangat terkait dengan potensi sumberdaya alam yang dimiliki dan diistilahkan dengan 3S, yakni Sea (laut) yang terkait dengan keberadaan ekosistem terumbu karang, mangrove dan biota lainnya, Sun (matahari) yang terkait dengan kegiatan berjemur dan Sand (pasir) yang terkait dengan kegiatan rekreasi pantai. Kawasan wisata bahari harus tetap menjaga karakteristik ekosistem yang ada di dalamnya, karena I Gusti (2011) menyatakan bahwa wisata bahari adalah pasar khusus untuk orang yang sadar akan lingkungan dan tertarik untuk mengamati alam serta merupakan proses ekonomi dengan maksud memasarkan ekosistę̧ menarik dan langka.

Hal tersebut di dukung juga oleh The World Conservation Union (WCU) Yang menyatakan bahwa pembangunan pariwisata beykelanjutan adalah proses pembangunan suaturempat atau daerah tanpa mengurangi nilai guna dari sumber daya yang sudah ada. Pembangunan tersebut dicapai melalui pengawasan dan pemeliharaan terhadap sumber-sumber daya ałam, agar dapat dinikmati untuk masa yang akan datang. Sedangkan menurut World Côtmission on Environment and Development konsep pariwisata berkelanjutan adalah bagian dâri pembangunan berkelanjutan yang memperhattkan kebutuhan saat ini dengan mempertimbangkan kebutuhan generasi penerus di waktu yang akan datang (I Gusti, 2011).

Berdasarkan pendapat di atas, maka pengelolaan wisata bahari di perairan Bandengan harus tetap memanfaatkan sumberdaya alam yang ada pada saat ini secara optimal tetapi harus tetap memperhatikan keberlanjutan kawasan dalam jangka yang panjang agar dapat dinikmati oleh generasi berikutnya. Penataan ruang, peningkatan sarana dan prasarana, sumberdaya manusia serta peraturan perundang-undangan yang akan ditetapkan dalam pengelolaan kawasan wisata bahari di perairan Bandengan harus mengoptimalkan sumberdaya alam saat ini dengan tetap memperhatikan kelestarian dan keberlanjutan kawasan wisata bahari tersebut.

\section{KESIMPULAN}

Indeks kesesuaian wisata di perairan Bandengan yang terdiri dari empat kategori wisata bahari yaitu rekreasi dan renang, selam permukaan, selam dan berperahu, banana boat dan jet ski menghasilkan kategori sangat sesuai untuk kategori rekreasi dan renang serta berperahu, banana boat dan jet ski. Sedangkan wisata bahari kategori selam permukaan dan selam berdasarkan indeks kesesuain wisata termasuk dalam kategori yang tidak sesuai. 
Analisa daya dukung kawasan di perairan Bandengan dihitung berdasarkan indeks kesesuaian kawasan. Berdasarkan hasil analisa tersebut, hanya terdapat dua kategori wisata bahari yang memenuhi syarat untuk dilakukan perhitungan terhadap daya dukung kawasan. Kategori tersebut adalah rekreasi dan renang dengan luas 52,46 ha dengan daya tampung kawasan sebanyak 27.978 wisatawan dan kategori berperahu, banana boat dan jet ski diperoleh luas kawasan sebesar 99,68 ha sehingga dengan daya tampung sebanyak 11.961 wisatawan. Faktor pembatas utama untuk wisata bahari kategori selam permukaan dan selam adalah kecerahan perairan dan ekosistem terumbu karang yang berada dalam kondisi buruk, sehingga diperlukan adanya rehabilitasi terutama ekosistem terumbu karang.

\section{DAFTAR PUSTAKA}

Bahar A dan Rahmadi T. 2011. Analisis Kesesuaian dan Daya Dukung Kawasan Wisata Bahari di Kabupaten Polewali Mandar. Fakultas Ilmu Kelautan dan Perikanan, Universitas Hasanuddin. Makassar. 18p.

Bakosurtanal. 1999. Peta Rupa Bumi Indonesia, Skala $1: 25.000$.

Bakosurtanal. 2000. Peta Lingkungan Pantai Indonesia, Skala $1: 50.000$.

Birkeland C. 1989. The Influence of Echinoderm on Coraf Reef Communities. In: M Jangoux \& JM Lawrence (eds.) Echinoderms Studies. Balkema, Rotterdam, Netherland $3: 79$ p.

Burke L, Selig E, and Spalding M. 2002. Reefs at Risk in Southeast Asia. World Resource Institute, Washington DC, USA. 72p.

Citra Satelit Quick Bird. 2007.

Dahuri R. 2003. Keanekaragaman Hayati Laut Aset Pembangunan Berkelanjutan Indonesia, PT. Gramedia Pustaka Utama, Jakarta. 412p.

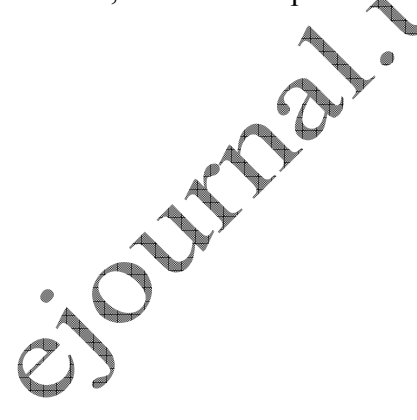

Dinas Kelautan dan Perikanan. 2010. Buku Saku. Pemerintah Kabupaten Jepara. Dinas Kelautan dan Perikanan. 58p.

Dodds R. 2007. Malta's Tourism Policy: Standing Still or Advancing Towards Sustainability. Island Studies Journal, 2 (1): 47-66.

Edward, Muhajir, Fasmi A dan Rozak A, 2004. Pengamatan Beberapa Sifat Kimia dan Fisika Air Laut di Ekosistem Terumbu Karang Pulau Sipora dan Siberut Kepulauan Mentawai Sumatera Barat. Jurnal Ilmiah Sorini, III (01): 38-60.

Haris JM dan Godwin. 2002. A Survey of Sustainable Development: Social and Economic Dimensions. The Global Development and Environment Institute Tufts University.

Hernández JC, Brito A, García N, Gil-Rodríguez MC, Herrera G, Reyes AC, Falcón JM. 2006. Spatial and Seasonal Variation of the Gonad Index of Diadema antillarum (Echinodermata: Echinoidea) in the Canary Islands. Scientia Marina, 70 (4): 132-145.

Hunger DJ. and Wheelen TL. 2003. Strategic Management. Edisi Bahasa Indonesia diterbitkan oleh Penerbit Andi, Yogyakarta.

I Gusti Agung Gede Oka Gautama. 2011. Evaluasi Perkembangan Wisata Bahari di Pantai Sanur. Prog. Pascasarjana, Universitas Udayana, Denpasar.

Pragawati B, 2009. Pengelolaan Sumberdaya Pesisir untuk Pengembangan-Wisata Bahari di Pantai Binangun Kabupaten Rembang Jawa Tengah. Fakultas Perikanan dan Ilmu Kelautan, Institut Pertanian Bogor, Bogor.

RiyladíA, Kestario W dan Kusno W. 2005. Kajian Kualitas Rerairan Laut Kota Semarang dan Kelayakannya untuk Budidaya Laut. J. Tek. Ling. P3TL-BPPT. 6 (3): 497-501.

Senoaji G. 2009. Daya Dukung Lingkungan dan Kesesuaian Lahan dalam Pengembangan Pulau Enggano Bengkulu. Jurnal Bumi Lestari 9(2): 159-166.

Supriharyono MS. 2007. Pengelolaan Ekosistem Terumbu Karang. Penerbit Djambatan, Jakarta.

Yulianda F. 2007. Ekowisata Bahari Sebagai Alternatif Pemanfaatan Sumberdaya Pesisir Berbasis Konservasi. Standar Sains. Departemen Manajemen Sumberdaya Perairan. Fakultas Perikanan dan Ilmu Kelautan, Institut Pertanian Bogor. Bogor. 